\title{
Distribution of meiobenthos in the Nazaré canyon and adjacent slope (western Iberian Margin) in relation to sedimentary composition
}

\author{
R. Garcia ${ }^{1, *}$, K. A. Koho ${ }^{2}$, H. C. De Stigter ${ }^{3}$, E. Epping ${ }^{3}$, E. Koning ${ }^{3}$, L. Thomsen ${ }^{1}$ \\ ${ }^{1}$ Jacobs University Bremen, Campus Ring 1, 28759 Bremen, Germany \\ ${ }^{2}$ University of Utrecht, Faculty of Geosciences, Budapestlaan 4, 3584 CD, Utrecht, The Netherlands \\ ${ }^{3}$ Royal Netherlands Institute for Sea Research (NIOZ), 1790 AB Den Burg, Texel, The Netherlands
}

\begin{abstract}
Abundance of metazoan meiofauna and foraminifera, and biomass and community structure of nematodes, were investigated in the benthic zone along the Nazaré Canyon and adjacent continental slope in relation to concentration of organic matter and its suitability as a food source for the meiobenthos. The Nazaré canyon sediments were richer in organic carbon (Corg), total nitrogen, and phytopigments than the adjacent open slope. In addition, phytodetritus was fresher in the canyon sediment than on the slope (higher chlorophyll a: phaeopigments). Nevertheless, the abundance of polychaetes, copepods, bivalves, nematodes, total metazoans, and nematode biomass were not always higher in the canyon than on the adjacent open slope. Lower densities occurred in the upper and middle canyon, and living benthic foraminifers were significantly more abundant on the adjacent slope. The stations in the upper and middle canyon contained infinitesimal numbers of foraminifers. Reduced diversity and evenness and high $K$-dominance of the nematode assemblages in the upper part of the canyon indicated environmental stress, perhaps related to high Corg content and sediment disturbance. Non-selective deposit-feeders dominated the nematode assemblages of the upper and middle parts of the canyon, whereas a more diverse trophic structure was found in the deeper parts and the open slope. Conditions in the upper and middle areas of the Nazaré canyon are harsh, and only opportunistic organisms can survive there.
\end{abstract}

KEY WORDS: Nazaré canyon $\cdot$ Meiobenthos $\cdot$ Foraminifera $\cdot$ Sedimentary organic carbon $\cdot$ Physical disturbance

\section{INTRODUCTION}

Deep gullies and submarine canyons run perpendicular to the shoreline and can dissect the entire continental shelf and slope. Canyons can trap part of the suspended particulate organic matter transported along the continental margin, and serve as conduits for organic particles and sediments from the shelf and upper slope to the deep sea (Van Weering et al. 2002). Therefore, they represent areas of high sedimentary organic carbon (Corg) content and relatively high biochemical activity (Epping et al. 2002). Furthermore, some submarine canyons are very unstable environments, since tidal currents, episodic slumps and turbidity flows periodically transport sediments and organic particles into the canyon system (Puig et al. 2004). Currents inside canyons can reach velocities of $2 \mathrm{~m} \mathrm{~s}^{-1}$ (Vetter \& Dayton 1998).

In the Nazaré canyon, sediments and fine particles are actively transported in nepheloid layers, and high sedimentation rates occur especially in its upper and middle regions (Van Weering et al. 2002). In the canyon, detritus of terrigenous origin predominates over pelagic detritus, and there is a higher 
Corg content than in the open continental shelf and slope (Epping et al. 2002, Van Weering et al. 2002). Enhanced remineralisation rates have been shown as a result of enrichment with Corg (Epping et al. 2002).

Meiofaunal communities are responsible for a significant amount of sediment remineralisation and support significant trophic pathways (Leguerrier et al. 2003). According to Tietjen (1992), on average, bacteria comprise $86 \%$, macrofauna $7 \%$ and meiofauna $5 \%$ of living carbon in deep-sea sediments. Hence, despite comprising a relatively minor component of the living carbon compared to bacteria, macro- and meiofauna play an important role in the total carbon turnover of deep-sea environments. The meiofauna communities in the Nazaré canyon have rarely been studied: a few records of metazoan meiobenthos are available for the Western Iberian Margin (see Soltwedel 2000, Flach et al. 2002), while Flach (2003) reported very high densities of meiofauna in the canyon at all depths.

Benthic animal communities from canyon systems can reflect the unstable and organically enriched conditions of these systems. Indeed, the fauna communities inhabiting submarine canyons have been found to differ in structure from those on adjacent abyssal plains, continental shelf, or slope. Faunal densities and biomasses in canyon systems have been found to be higher (e.g. Gage et al. 1995, Vetter \& Dayton 1998, Duineveld et al. 2001) and faunal diversities lower (e.g. Gage et al. 1995, Vetter \& Dayton 1998, Curdia et al. 2004) than in adjacent habitats. These differences in faunal structure have been attributed to the higher organic content of canyon systems (see Gage et al. 1995, Duineveld et al. 2001). However, there are indications that abundances can also be lower in canyons than in adjacent areas (see Maurer et al. 1994); this could be related to factors other than the high Corg content of these systems. In the Nazaré canyon, Flach (2003) reported lower numbers of macrofauna than on the Iberian continental slope. Polychaetes dominated the macrofauna in this canyon, and opportunistic polychaete communities occurred in regions with high organic matter content (Flach 2003, Curdia et al. 2004). Furthermore, macrofauna biomass in the canyon increases with increasing Corg fluxes (Flach 2003).

The present study investigated changes in the composition of meiofaunal assemblages along a depth gradient in the Nazaré canyon and the adjacent open slope. Organic matter concentrations and lability were also studied to investigate whether the content and freshness of the sedimentary organic matter in the canyon were the main driving factors controlling the meiobenthic community.

\section{MATERIALS AND METHODS}

Study area. The Nazaré canyon is the largest canyon on the Western Iberian Margin, and intersects the entire continental shelf (Vanney \& Mougenot 1981). Inside the canyon there is a strong internal tide circulation of water, with velocities of up to $15 \mathrm{~cm} \mathrm{~s}^{-1}$ (Coelho et al. 2003). Sediment transported over the shelf and upper slope by alongshore currents is temporarily deposited in the very narrow upper and middle part of the canyon, until it is further transported to the deep sea in nepheloid layers or flushed down canyon by turbidite currents (Van Weering et al. 2002, Garcia et al. 2003).

The hydrography of the shelf is dominated by a poleward current in winter and an equatorward current during summer (Vitorino et al. 2002, Coelho et al. 2003). The poleward current favours downwelling, while the equatorward current is generally associated with coastal upwelling, which triggers high primary production along the Iberian Margin (Vitorino et al. 2002).

The canyon is characterised by a well-stratified water column. North Atlantic Deep Water (NADW) with temperatures of 2 to $7^{\circ} \mathrm{C}$ and salinities of 34.8 to $35.6 \mathrm{ppm}$ is present between depths of approximately 2000 and $3000 \mathrm{~m}$ water depths (Garcia et al. 2003). Between approximately 600 and $1500 \mathrm{~m}$, Mediterranean water is present, with temperatures of 8 to $13^{\circ} \mathrm{C}$ and salinities of 35.8 to $36.2 \mathrm{ppm}$. Temperatures of 14 to $18^{\circ} \mathrm{C}$ and salinities of 35.4 to $35.8 \mathrm{ppm}$ characterise the upper water layer.

Sampling. Sediment cores for meiofauna and physicochemical analyses were collected in May 2004 during Cruise 64PE225 of the RV 'Pelagia'. For this study we analysed data from 8 stations located along a depth gradient in the Nazaré canyon axis (S41, S26, S34, S24 and S22) and adjacent open slope (S39, S27 and S25) (Fig. 1). Sediment samples for physicochemical and faunal analyses were taken with the MUC 8+4 multiple corer developed by Octopus $\mathrm{GmbH}$. This corer has an array of eight $6 \mathrm{~cm}$ diameter and four $10 \mathrm{~cm}$ diameter coring tubes, $61 \mathrm{~cm}$ in length. For each station, three $10 \mathrm{~cm}$ multicorer tubes were used for metazoan analysis, one $10 \mathrm{~cm}$ tube for sedimentological analysis, three $6 \mathrm{~cm}$ tubes for phytopigment analysis, and one $6 \mathrm{~cm}$ tube for foraminifer analysis. From a second deployment, four $6 \mathrm{~cm}$ tubes were used for analysis of total and organic $\mathrm{C}$ and $\mathrm{N}$. Cores were stored at in situ temperature in a temperature-controlled room and processed within $3 \mathrm{~h}$ of collection.

The sediment samples for phytopigment, total and organic $\mathrm{C}$ and $\mathrm{N}$ analysis were stored at $-20^{\circ} \mathrm{C}$ until analysis; 4 to 6 replicate sub-cores were taken from the core tubes for metazoan analysis using $60 \mathrm{ml}$ syringes 


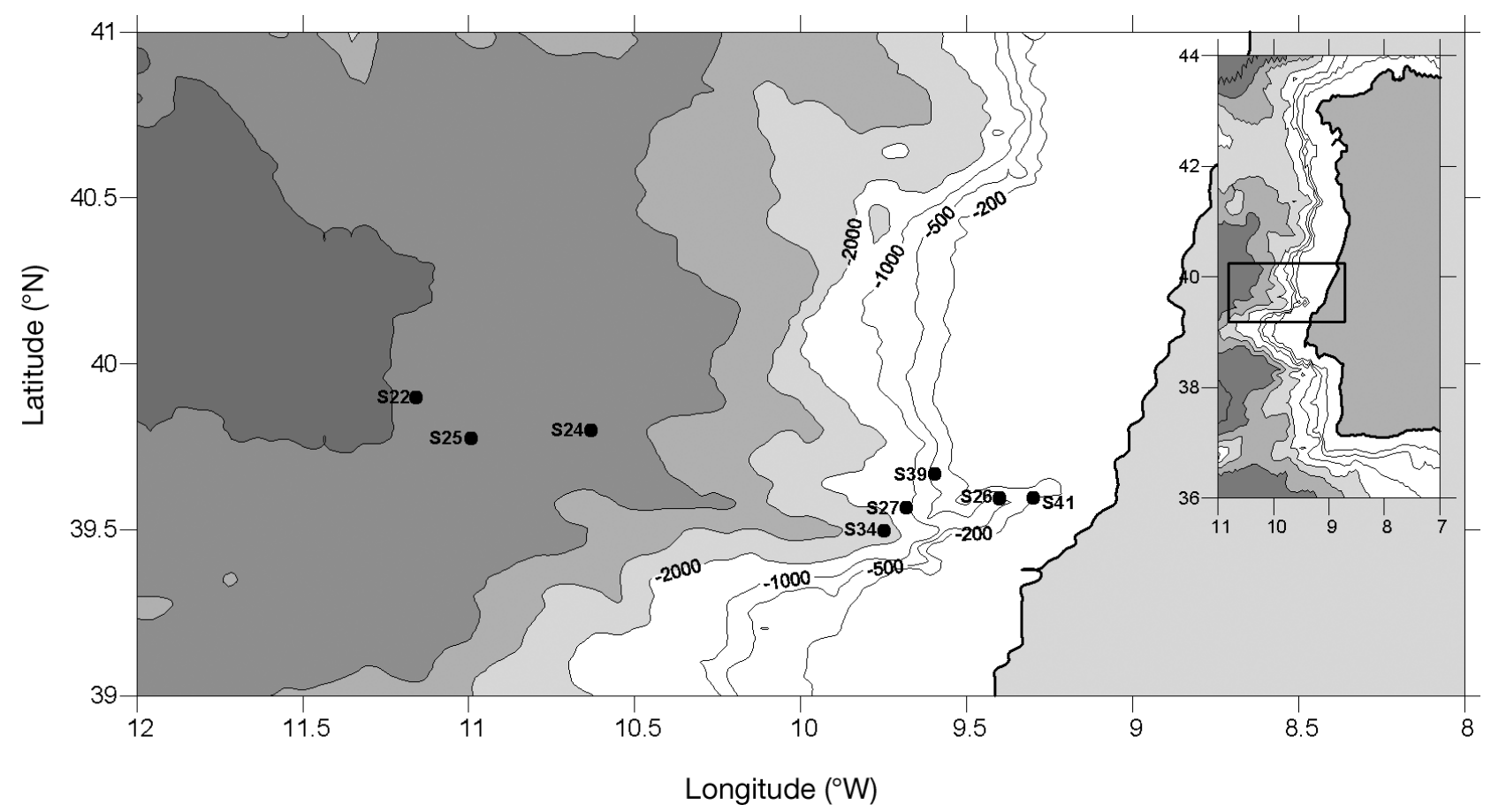

Fig. 1. Nazaré canyon showing stations sampled during cruise 64PE225

with cut-off anterior ends. These sediment samples were preserved in $4 \%$ buffered formaldehyde solution. The sediment samples from the core used for analysis of foraminifers were preserved in $96 \%$ ethanol solution with Rose Bengal. Only the upper $5 \mathrm{~cm}$ of the cores were used in this study.

Grain-size analysis. Sediment samples were freezedried, and then crumbled and mixed. Subsequently, $\sim 100 \mathrm{mg}$ of sediment was dispersed in water, applying ultrasound for mechanical dispersal but without addition of chemical dispersatives. The dispersed sediment was then introduced into a Coulter LS 230 laser particle-sizer for determination of particle size spectra.

Geochemical analysis. Phytodetritus input to the seafloor was assessed by fluorometric measurement of sediment-bound chlorophyll a ( $\mathrm{chl}$ a) and phaeopigment (phaeo) concentrations following the method of Yentsch \& Menzel (1963). Sediment samples were first freeze-dried and homogenised in a mortar. Pigments were subsequently extracted in $10 \mathrm{ml} 90 \%$ acetone solution and measured in a Turner fluorometer following Shuman \& Lorenzen (1975). The bulk of pigments measured with this method were termed 'chloroplastic pigment equivalents', CPE (Thiel 1978). Chl a versus phaeo concentrations were used to assess the fresh organic matter of photosynthetic origin that reached the seafloor.

Sediment total carbon, total nitrogen (TN) and Corg were measured using a ThermoFinnigan flash element analyser following the procedures described by Lohse et al. (2000).

Meiofauna analysis. In the laboratory, sediment samples for metazoan investigations were washed through a $48 \mu \mathrm{m}$ sieve and metazoans were extracted using Ludox (colloidal silica polymer) diluted in water to a specific gravity of 1.209 (Ólafsson \& Elmgren 1997). The metazoans were counted and identified to major taxa in a Petri dish under a stereomicroscope. All the nematodes were picked and put in a watch glass with a glycerine solution (5\% glycerine, $5 \%$ pure ethanol and $90 \%$ distilled water). After $24 \mathrm{~h}$ at $50^{\circ} \mathrm{C}$, the nematodes were mounted on micro-slides, using anhydrous glycerine as mounting medium, for identification to genus under a compound microscope. To estimate nematode biomasses, nematode length (excluding filiform tails) and width were measured by the semiautomatic images system (analySIS $® 2.1$ ) at the Alfred Wegener Institute. Nematode volume and biomass (wet weights) were calculated using Andrassy's (1956) formulas. Nematode wet weights were then converted into carbon biomass assuming that $100 \%$ wet weight corresponds to $12.4 \%$ carbon weight (Jensen 1984). Nematode feeding types (1A, 1B, 2A and 2B) were determined after the classification provided by Wieser (1953).

Sediment samples for investigations of foraminifers were washed through 150 and $63 \mu \mathrm{m}$ sieves. Only the $150 \mu \mathrm{m}$ fraction was used for this study. Well-stained 
foraminifers were counted in a Petri dish under a stereomicroscope, and transferred to Chapman slides for identification. For the quantification of arborescent foraminifers (a type of branching agglutinant foraminifer), a standard minimum size of $1.5 \pm 0.1 \mathrm{~mm}$ was adopted because these foraminifers can easily break apart when sorting. The estimate of total individuals thus included fragments of various sizes.

Data analysis. Shannon-Wiener diversity index $H^{\prime}$ (Krebs 1989), evenness $J^{\prime}$ (Pielou, 1969) and $K$-dominance curves (Lambshead et al. 1983) were calculated for the nematode assemblage at each site.

Univariate 2-way ANOVAs were used to investigate differences in faunal abundance, nematode biomass, diversity and evenness between the 2 locations (i.e. canyon vs. open slope) and between different water depths. A nested design was constructed with depth nested within location. A 1-sample KolmogorovSmirnov test was used to check the normality of the taxa counts, nematode biomass data and ecological indices. The data was not normally distributed, and was therefore $\log _{2}(\mathrm{x}+1)$-transformed prior to ANOVA analysis. To test for possible relationships between the various meiofaunal and geochemical parameters and for possible differences between the Nazaré canyon and the adjacent open slope, 2 non-parametric correlation analyses were performed; one with canyon data the other with open-slope data. The Kendall's tau statistic from the statistical package SPSS 12.0 was used, as this is extremely conservative, with a low number of measurements.

\section{RESULTS}

\section{Sediment granulometry}

Sediments in the canyon were predominantly muddy (silt and clay), except at Stns S26 and S34 (Table 1), where silt and clay comprised only about $50 \%$ of the sediment, with the other $50 \%$ consisting of sand, and the finer material occurring in the top centimetres. On the open slope, sediments became muddier with increasing water depth. In the shallow open-slope station (S39), about $35 \%$ of the sediment particles were silt and clay, whereas in the deepest open-slope (S25) station about $98 \%$ of the sediment particles were silt and clay.

\section{Geochemical characteristics of sediments}

The canyon sediments were organically enriched compared to the adjacent open slope (Table 1), containing higher $\mathrm{CPE}$, a measure of phytodetritus con-

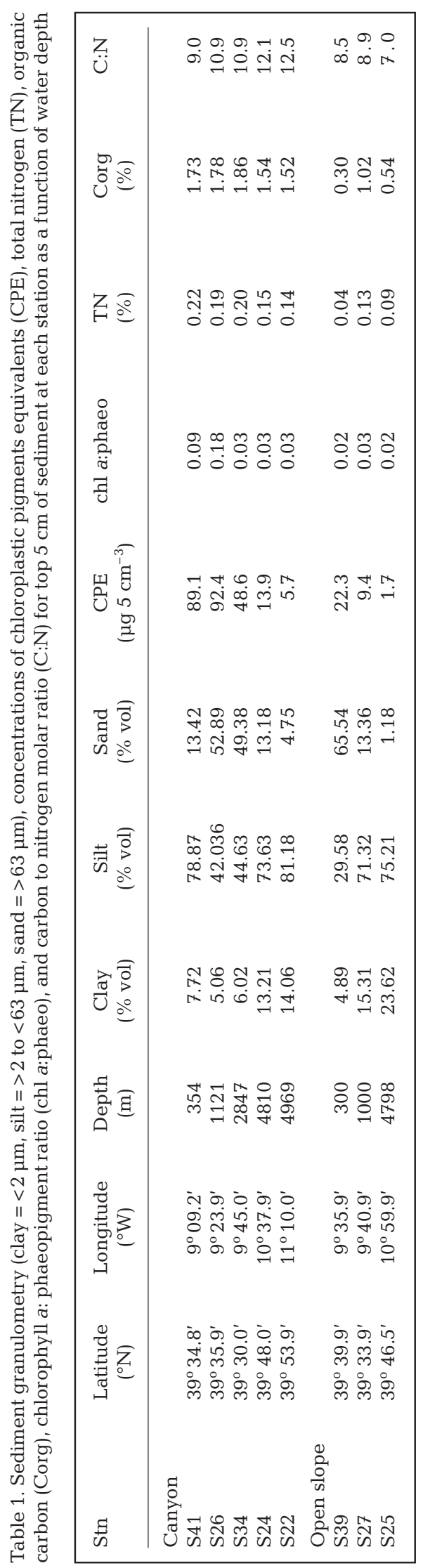


tent. The upper part of the canyon (Stns S41 and S26) had the highest CPE values, which decreased with increasing water depth. Furthermore, the quality of the phytodetritus was highest in the upper part of the canyon (Stns S41 and S26) (chl a:phaeo $=0.09$ to 0.18 ), and TN and Corg contents were also higher in the canyon, especially in the upper and middle parts (Stns S41, S26 and S34). The canyon detritus had a higher proportion of terrigenous organic matter ( $\mathrm{C}: \mathrm{N}=9$ to 12.5) than open-slope detritus.

On the open slope, CPE values were low, decreasing with increasing water depth. The quality of the phytodetritus was low and similar to the quality at the middle and deeper parts of the canyon. TN and Corg contents were lower than in the canyon, and the detritus had a higher proportion of organic material of pelagic origin ( $\mathrm{C}: \mathrm{N}=7$ to 8.9 ).

\section{Meiofauna}

We identified a total of 12 major taxa within the 2 study areas. Nematodes were the most abundant group within the canyon and the adjacent open slope, comprising between 40 and $90 \%$ of total metazoan abundance (Fig. 2). Copepods were the second most abundant group in both study areas, comprising between 10 and $40 \%$ of total metazoan abundance, followed by polychaetes. Bivalves were more abundant in the canyon stations, but in low percentages, except at Stn S34. Amphipoda, Cumacea, Decapoda, Ostracoda, other Crustacea, Kinorincha and Halcaroidea occurred occasionally and in very low numbers,

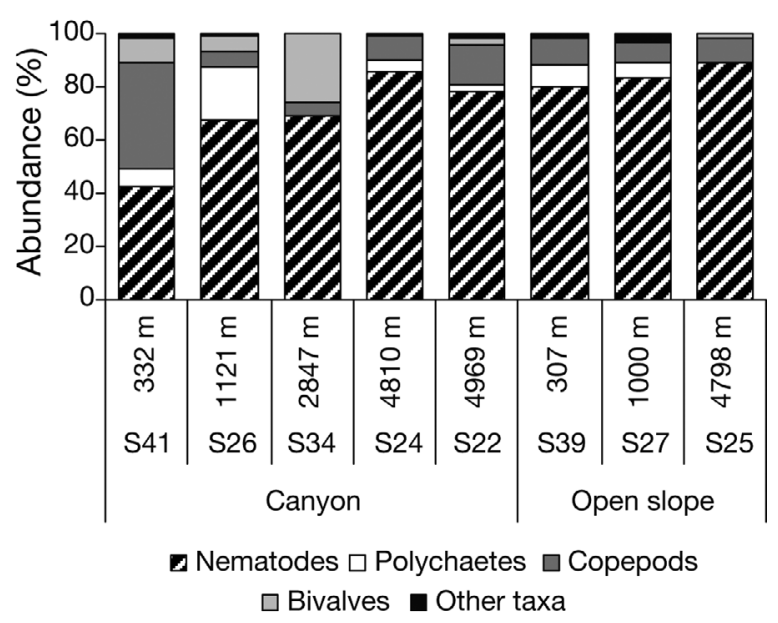

Fig. 2. Relative abundance of nematodes, polychaetes, copepods, bivalves and minor taxa along a depth gradient at Stns S41, S26, S34, S24, S22, S39, S27 and S25 in Nazaré canyon and on adjacent open slope being insignificant in terms of abundance. On average, these taxa together represented about 1 to $2 \%$ of the total meiofauna. These taxa will not be analysed below in more detail.

Foraminiferal abundance is not expressed as a percentage of total meiofauna because foraminifers were only investigated in the $>150 \mu \mathrm{m}$ fraction, the $>48 \mu \mathrm{m}$ fraction being used to examine metazoans abundance.

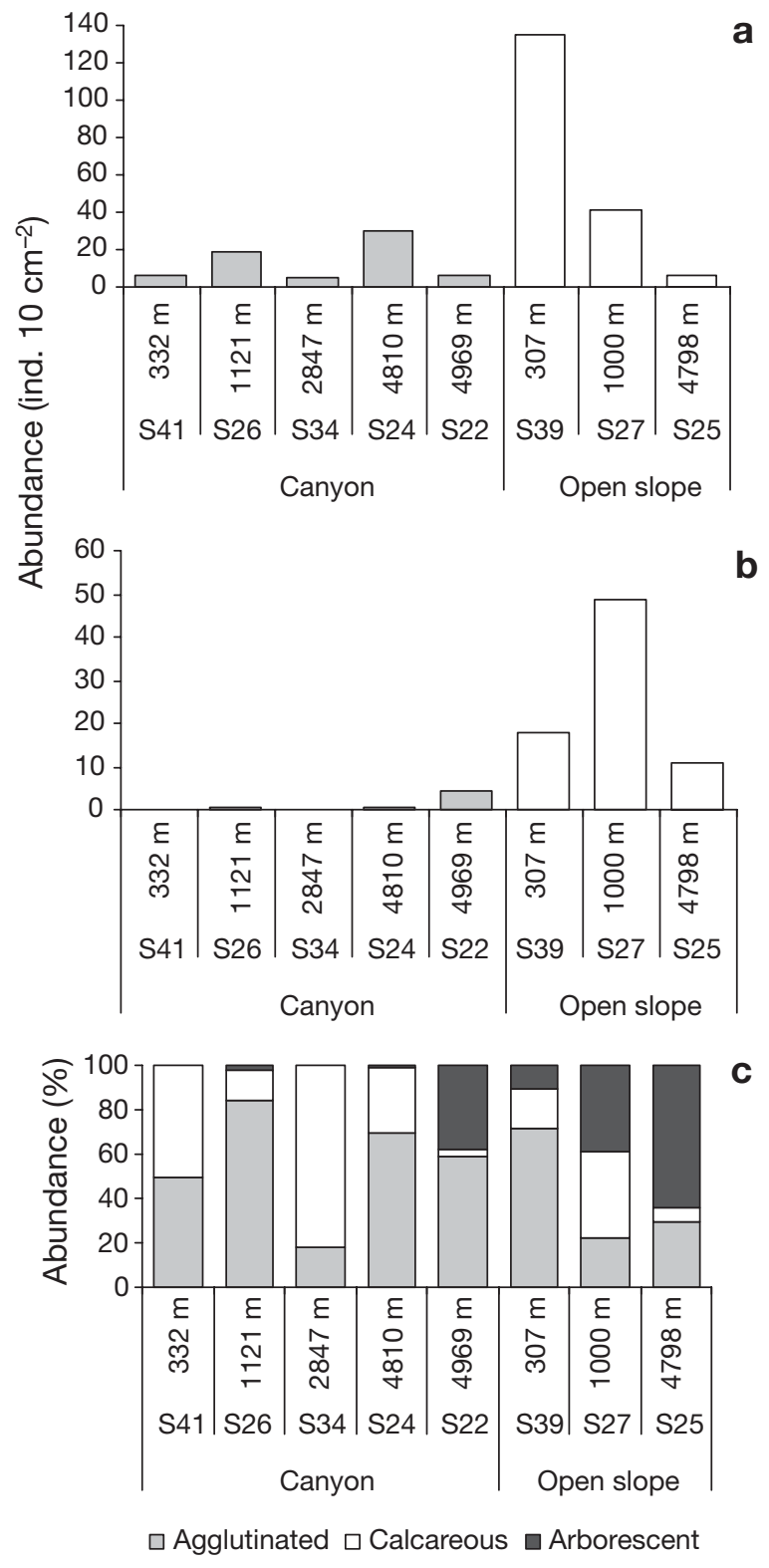

Fig. 3. (a,b) Abundance of total standing stock of (a) agglutinated and calcareous foraminifers and (b) arborescent foraminifers, and (c) relative abundance of agglutinated, calcareous and arborescent foraminifers, along bathymetric gradient and at Stns S41, S26, S34, S24, S22, S39, S27 and S25 in the Nazaré canyon and on adjacent open slope $(\mathrm{n}=1$, data from one replica) 

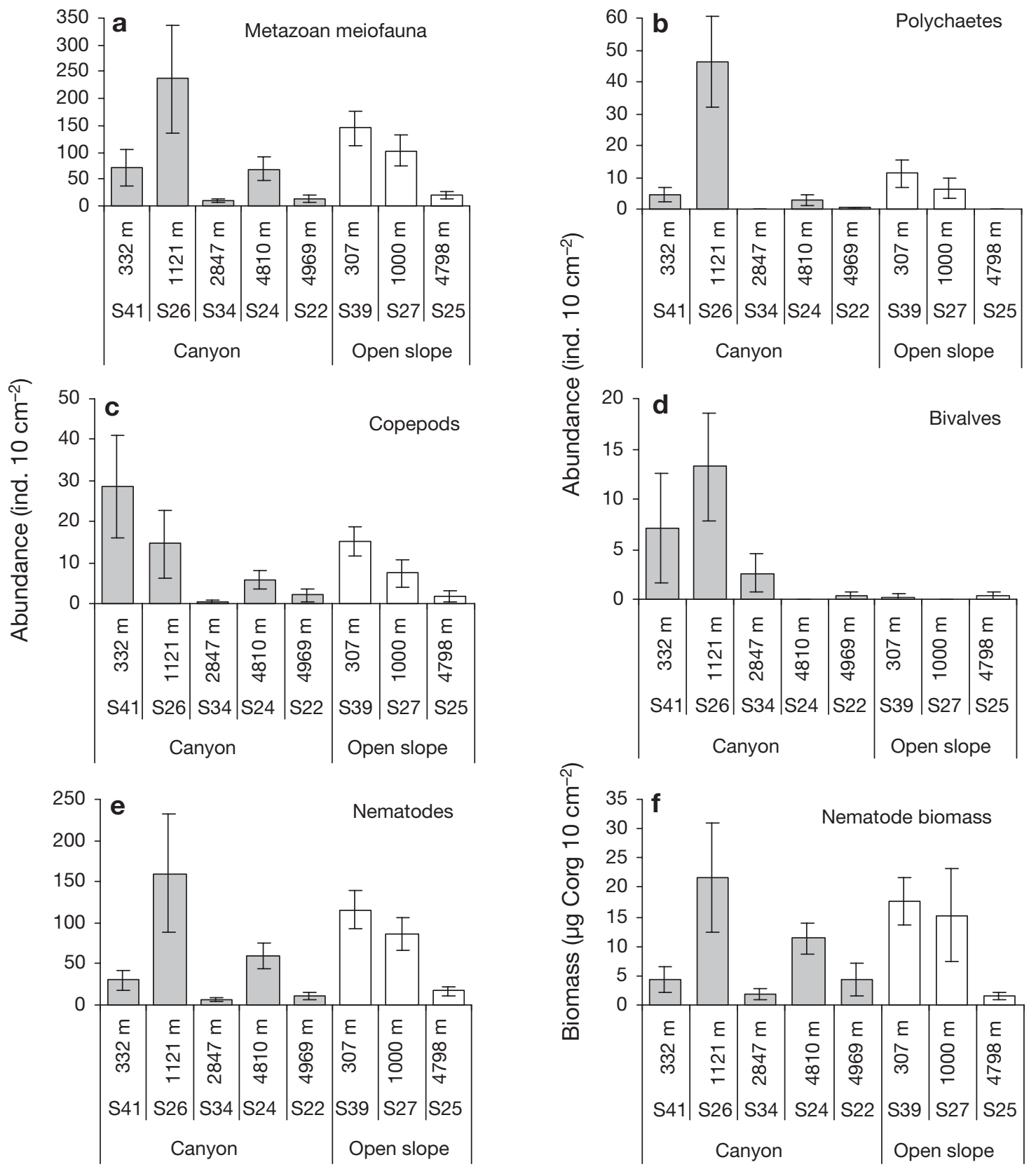

Fig. 4. (a) to (e) Mean \pm SE abundance of (a) metazoan meiofauna, (b) polychaetes, (c) copepods, (d) bivalves and (e) nematodes, and (f) nematode biomass (Corg $10 \mathrm{~cm}^{-2}$ ) along bathymetric gradient and at Stns S41, S26, S34, S24, S22, S39, S27 and S25 in

Nazaré canyon and on adjacent open slope

\section{Foraminifera}

Low to insignificant numbers of foraminifers were recorded in the upper and middle canyon (Fig. 3a). The highest total standing stocks were found in the deep canyon station, S24. Below this station the system widens into a fan, and foraminifer abundances here were similar to those on the nearby slope. In contrast, high total standing stocks of foraminifers were recorded along the open slope, displaying a clear decreasing trend with increasing water depth.

Elevated numbers of arborescent foraminifers (branching agglutinant) were observed in the open-slope sediments, most being recorded at Stn S27 (Fig. 3b). In the canyon arborescent foraminifers were almost completely absent, with the exception of Stn S22 at the lower end of the canyon. 
In general, the canyon stations were dominated by agglutinated foraminifers (Fig. 3c), representing between the 60 and $80 \%$ of all individuals; the only exception being Stn S34, where $>80 \%$ of the assemblage comprised calcareous foraminifera. At the head of the canyon (Stn S41), calcareous and agglutinated foraminifers were present in similar numbers. At the open-slope stations, arborescent, calcareous and agglutinated foraminifers were well represented. Agglutinated foraminifers dominated at the shallow openslope station accounting for $70 \%$ of total foraminifers abundance. At $1000 \mathrm{~m}$ (Stn S27), calcareous and arborescent foraminifers were numerically dominant (80\% of all individuals). The deepest site was numerically dominated by arborescent foraminifers ( $>60 \%$ of all individuals).

\section{Metazoans}

On the open slope, the abundance of most taxonomical groups and also nematode biomass decreased with increasing water depth (Fig. 4a,b,c, e,f). In contrast, in the canyon no clear decrease was observed. Stn S26 at $1121 \mathrm{~m}$ contained the highest abundance of most taxonomical groups and also the highest nematode biomass (Fig. 4a,b,d,e,f). The only depth-related pattern in the canyon was that the highest abundance of taxa and highest nematode biomass occurred in the upper part of the canyon (Stns S41 and S26).

Statistically, there were significant inter-station differences in the abundances of metazoans and nematode biomass as a function of depth at each location (canyon and open slope) (all p $\leq 0.001$, Table 2). There were also significant differences in the mean abundance of nematodes and bivalves between the canyon and the slope $(\mathrm{p} \leq 0.004$ and $\mathrm{p} \leq 0.001$ respectively, Table 2). Mean abundance of nematodes was lower in

Table 2. Results of univariate 2-way nested ANOVA; df = 1 and 5 for Location and Depth(Location) respectively. Nem.: nematode

\begin{tabular}{|lrrrr|}
\hline \multirow{2}{*}{ Parameter } & \multicolumn{2}{c}{ Location } & \multicolumn{2}{c|}{ Depth(Location) } \\
& $F$ & $\mathrm{p} \leq$ & $F$ & $\mathrm{p} \leq$ \\
\hline Total meiofauna & 3.249 & 0.081 & 14.410 & 0.001 \\
Polychaeta & 0.444 & 0.510 & 22.744 & 0.001 \\
Nematoda & 9.606 & 0.004 & 11.548 & 0.001 \\
Copepoda & 0.119 & 0.732 & 12.941 & 0.001 \\
Bivalvia & 24.514 & 0.001 & 8.775 & 0.001 \\
Nem. biomass & 1.866 & 0.181 & 8.724 & 0.001 \\
Diversity $\left(H^{\prime}\right)$ & 52.189 & 0.001 & 11.247 & 0.001 \\
Eveness $\left(J^{\prime}\right)$ & 5.735 & 0.023 & 2.335 & 0.065 \\
\hline
\end{tabular}

the canyon than on the slope $\left(53.5 \pm 21.1\right.$ ind. $10 \mathrm{~cm}^{-2}$ and $73.1 \pm 16.4$ ind. $10 \mathrm{~cm}^{-2}$, respectively, mean $\pm \mathrm{SE}$ ), and mean abundance of bivalves was higher in the canyon $\left(4.6 \pm 2.6\right.$ ind. $10 \mathrm{~cm}^{-2}$ and $0.2 \pm 0.2$ ind. $10 \mathrm{~cm}^{-2}$, respectively).

\section{Nematode assemblage}

A total of 85 genera of nematodes was recorded (Table 3). For the canyon a total of 55 genera was recorded, of which only 3 (Metalinhomoeus, Sabatieria and Sphaerolaimus) were present at all canyon stations and 16 genera were exclusively present in the canyon. The open slope had a total of 68 genera, of which 11 (Acantholaimus, Camacolaimus, Cervonema, Halaimus, Marylinia, Metalinhomoeus, Neochromadora, Paralongicyatholaimus, Sabatieria, Sphaerolaimus and Terschellingia) were present at all open-slope stations and 31 genera were exclusively present in the open slope (Table 3). Metalinhomoeus and Sabatieria were the most abundant genera for both canyon and open slope, being highest in the canyon.

The mean diversity $\left(H^{\prime}\right)$ and evenness $\left(J^{\prime}\right)$ indexes for the nematode assemblage were significantly higher on the open slope than in the canyon. Diversity on the slope was $2.3 \pm 0.1$ and $1.3 \pm 0.2$ in the canyon $(\mathrm{p} \leq$ 0.001 , Table 2). Evenness was $0.9 \pm 0.01$ on the slope and $0.7 \pm 0.1$ in the canyon $(\mathrm{p} \leq 0.023$, Table 2$)$. Diversity decreased with increasing water depth on the open slope (Fig. 5a). In the canyon, it only did so in the upper and middle parts. Evenness did not change along the depth gradient on the slope (Fig. 5b), and in the canyon, Stns S26 and S34 had lower evenness values than the remaining canyon stations. Inter-station differences in diversity with depth at each location (canyon and open slope) were statistically significant ( $\mathrm{p} \leq$ 0.001, Table 2).

$K$-dominance curves of nematode abundance (Fig. 6) revealed 2 groups of curves in the canyon and 1 in the open slope. The curves for Stns S26, S34 and S41 indicated higher nematode dominance within these assemblages than at Stns S24 and S22 (Fig. 6a). In addition, the curves for Stns S24 and S22 were similar to those for the 3 open-slope stations (Fig. 6b), indicating that all these stations had similar nematode dominance.

The trophic structure of the nematode assemblages differed between canyon and open slope. On the open slope, the four different feeding types of Wieser (1953) were well represented in terms of abundance (Fig. 7a) and biomass (Fig. 7b), and no differences in the trophic structure were observed along the depth gradient. In contrast, in the canyon, non-selective deposit-feeding 
Table 3. List of nematode genera - showing feeding type, FT (Wieser 1953) - and mean \pm SE abundance (ind. $10 \mathrm{~cm}^{-2}$ ) for Nazaré canyon and adjacent open-slope stations $(1 \mathrm{~A}=$ selective deposit-feeder, $1 \mathrm{~B}=$ non-selective deposit feeder, $2 \mathrm{~A}=$ epigrowth feeder, and $2 \mathrm{~B}=$ predator/omnivore)

\begin{tabular}{|c|c|c|c|c|c|c|c|c|c|}
\hline Genera & FT & \multicolumn{3}{|c|}{ Canyon system } & $\mathrm{S} 24$ & $\mathrm{~S} 22$ & S39 & $\begin{array}{l}\text { Open slope } \\
\text { S27 }\end{array}$ & S25 \\
\hline Acantholaimus & $2 \mathrm{~A}$ & & $2.1 \pm 1.4$ & $1.4 \pm 0.9$ & $1.4 \pm 1.4$ & & $0.9 \pm 0.9$ & $4.6 \pm 1.2$ & $1.4 \pm 0.6$ \\
\hline Amphimonhystrella & $1 \mathrm{~B}$ & & & & & $0.2 \pm 0.2$ & & & $0.4 \pm 0.4$ \\
\hline Araeolaimus & $1 \mathrm{~A}$ & & & & $0.3 \pm 0.3$ & & $0.2 \pm 0.2$ & & \\
\hline Ascolaimus & 1B & & & & & & $0.7 \pm 0.5$ & & \\
\hline Axonolaimus & $1 \mathrm{~B}$ & $0.5 \pm 0.3$ & $3.3 \pm 1.2$ & & & & $4.7 \pm 2.1$ & & \\
\hline Bathyeuristomina & $2 \mathrm{~B}$ & & & & & & & $0.4 \pm 0.4$ & \\
\hline Camacoliamus & $2 \mathrm{~A}$ & & & & $0.6 \pm 0.3$ & & $0.5 \pm 0.3$ & $0.4 \pm 0.4$ & $0.4 \pm 0.4$ \\
\hline Campylaimus & 1B & & $0.2 \pm 0.2$ & & & & $1.2 \pm 1.2$ & & \\
\hline Cervonema & $1 \mathrm{~B}$ & & $0.2 \pm 0.2$ & & $0.3 \pm 0.3$ & $0.2 \pm 0.2$ & $3.5 \pm 0.8$ & $1.8 \pm 1.1$ & $0.4 \pm 0.4$ \\
\hline Chaetonema & $1 \mathrm{~B}$ & & & & & $0.5 \pm 0.4$ & $0.5 \pm 0.5$ & & \\
\hline Chromadora & $2 \mathrm{~A}$ & $0.7 \pm 0.5$ & $0.7 \pm 0.5$ & & $0.3 \pm 0.3$ & & $6.8 \pm 1.3$ & $1.4 \pm 1.0$ & \\
\hline Chromadorita & $2 \mathrm{~A}$ & $0.2 \pm 0.2$ & & & & & $0.5 \pm 0.3$ & & \\
\hline Comesa & $1 \mathrm{~B}$ & & & & & & & $0.4 \pm 0.4$ & \\
\hline Comesoma & 1B & & & & & $0.2 \pm 0.2$ & & & \\
\hline Crenopharynx & $1 \mathrm{~A}$ & & & & & & $0.7 \pm 0.5$ & $0.7 \pm 0.4$ & \\
\hline Cricolaimus & $2 \mathrm{~A}$ & & & & & & $0.2 \pm 0.2$ & & \\
\hline Cyatolaimus & $2 \mathrm{~A}$ & & & & & & $0.5 \pm 0.5$ & & \\
\hline Cylicolaimus & $2 \mathrm{~B}$ & & & & & & $3.1 \pm 2.8$ & & \\
\hline Daptonema & 1B & & $0.9 \pm 0.7$ & & & & $0.2 \pm 0.2$ & $0.7 \pm 0.7$ & \\
\hline Desmocolex & $1 \mathrm{~A}$ & & & & $0.3 \pm 0.3$ & & & & \\
\hline Desmodora & $2 \mathrm{~A}$ & & & & & & $5.2 \pm 4.1$ & $3.5 \pm 1.2$ & \\
\hline Desmolaimus & 1B & & $0.2 \pm 0.2$ & & & & & & \\
\hline Disconema & $1 \mathrm{~B}$ & & & & $0.3 \pm 0.3$ & & & $0.4 \pm 0.4$ & \\
\hline Diplopeltoides & $1 \mathrm{~A}$ & & & & & & & $0.7 \pm 0.4$ & $0.4 \pm 0.4$ \\
\hline Diplopeltula & $1 \mathrm{~A}$ & & & & & $0.2 \pm 0.2$ & $0.5 \pm 0.3$ & & $0.4 \pm 0.4$ \\
\hline Dolicholaimus & $2 \mathrm{~B}$ & & & & & & $0.2 \pm 0.2$ & & \\
\hline Dorylaimopsis & $2 \mathrm{~B}$ & & & & & & $0.2 \pm 0.2$ & $0.4 \pm 0.4$ & \\
\hline Elzalia & $1 \mathrm{~B}$ & & & & & $0.2 \pm 0.2$ & & $0.4 \pm 0.4$ & \\
\hline Endeolophos & $2 \mathrm{~A}$ & & & & & & & $0.7 \pm 0.4$ & $0.4 \pm 0.4$ \\
\hline Enoploides & $2 \mathrm{~B}$ & & & & $0.6 \pm 0.3$ & & & & \\
\hline Enoplolaimus & $2 \mathrm{~B}$ & $0.2 \pm 0.2$ & $0.5 \pm 0.5$ & & & & $0.2 \pm 0.2$ & & \\
\hline Filoncholaimus & $2 \mathrm{~B}$ & & & & & & $0.2 \pm 0.2$ & & \\
\hline Halalaimus & $1 \mathrm{~A}$ & $0.2 \pm 0.2$ & & & $0.8 \pm 0.6$ & & $4.2 \pm 1.6$ & $1.4 \pm 0.6$ & $0.4 \pm 0.4$ \\
\hline Hopperia & $2 \mathrm{~B}$ & & & & & & & $0.7 \pm 0.7$ & \\
\hline Kraspedonema & $2 \mathrm{~A}$ & & & & $0.3 \pm 0.3$ & & & & \\
\hline Laimella & $2 \mathrm{~A}$ & & & & & & $0.2 \pm 0.2$ & & \\
\hline Leptolaimus & $1 \mathrm{~A}$ & & & & $0.3 \pm 0.3$ & & & & \\
\hline Limhomoeus & $2 \mathrm{~A}$ & & & & & & $0.2 \pm 0.2$ & & \\
\hline Longicyatholaimus & $2 \mathrm{~A}$ & & & & $7.1 \pm 0.4$ & & $1.7 \pm 0.8$ & $0.7 \pm 0.4$ & \\
\hline Marylinnia & $2 \mathrm{~A}$ & $1.7 \pm 0.6$ & & & $0.8 \pm 0.6$ & & $6.4 \pm 0.9$ & $0.4 \pm 0.4$ & $1.4 \pm 0.8$ \\
\hline Metacyatholaimus & $2 \mathrm{~A}$ & & & & & $0.2 \pm 0.2$ & & & \\
\hline Metadesmolaimus & $1 \mathrm{~B}$ & & & & $0.3 \pm 0.3$ & & & & \\
\hline Metalinhomoues & $1 \mathrm{~B}$ & $13.0 \pm 5.6$ & $85.4 \pm 39.2$ & $3.1 \pm 1.1$ & $4.2 \pm 1.4$ & $0.4 \pm 0.2$ & $14.1 \pm 2.6$ & $11.3 \pm 1.7$ & $2.8 \pm 1.0$ \\
\hline Metoncholaimus & $2 \mathrm{~B}$ & $0.2 \pm 0.2$ & & & $0.6 \pm 0.3$ & & & & \\
\hline Microlaimus & $2 \mathrm{~A}$ & $1.2 \pm 0.4$ & & & $0.3 \pm 0.3$ & & $0.5 \pm 0.3$ & & $0.4 \pm 0.4$ \\
\hline Molgolaimus & $1 \mathrm{~A}$ & & & & & & & $0.4 \pm 0.4$ & \\
\hline Nemanema & $1 \mathrm{~A}$ & & & & $0.3 \pm 0.3$ & & & $0.7 \pm 0.7$ & $0.7 \pm 0.7$ \\
\hline Neochromadora & $2 \mathrm{~A}$ & $0.7 \pm 0.5$ & $0.2 \pm 0.2$ & $0.2 \pm 0.2$ & & & $8.0 \pm 2.2$ & $6.4 \pm 0.9$ & $1.1 \pm 0.7$ \\
\hline Neotonchus & $2 \mathrm{~A}$ & & & & $0.3 \pm 0.3$ & & & & \\
\hline Onchium & $2 \mathrm{~A}$ & & & & $0.3 \pm 0.3$ & & & & \\
\hline Oncholaimus & $2 \mathrm{~B}$ & & & & $0.3 \pm 0.3$ & & $0.2 \pm 0.2$ & & $0.4 \pm 0.4$ \\
\hline Oncholaimellus & $2 \mathrm{~B}$ & & & & & & & $0.7 \pm 0.7$ & \\
\hline Oxystomina & $1 \mathrm{~A}$ & $0.2 \pm 0.2$ & $0.2 \pm 0.2$ & & & $0.2 \pm 0.2$ & $0.9 \pm 0.6$ & $1.1 \pm 0.7$ & \\
\hline Paracanthonchus & $2 \mathrm{~A}$ & & & & $1.7 \pm 1.0$ & & & & \\
\hline Paracomesoma & $1 \mathrm{~B}$ & & & & $1.4 \pm 1.4$ & $0.2 \pm 0.2$ & & $0.4 \pm 0.4$ & \\
\hline Paracyatholaimus & $2 \mathrm{~A}$ & $0.2 \pm 0.2$ & & & $0.6 \pm 0.6$ & & $2.1 \pm 1.1$ & $1.8 \pm 1.8$ & \\
\hline Paradontophora & 1B & & & & & $0.2 \pm 0.2$ & & & \\
\hline Paralongicyatholaimus & $s 2 \mathrm{~A}$ & & $0.7 \pm 0.7$ & $0.5 \pm 0.3$ & $0.6 \pm 0.6$ & $0.7 \pm 0.5$ & $1.9 \pm 1.1$ & $0.4 \pm 0.4$ & $1.4 \pm 0.6$ \\
\hline Paramesacanthion & $2 \mathrm{~B}$ & & $0.2 \pm 0.2$ & & $1.7 \pm 1.0$ & & $0.5 \pm 0.3$ & & \\
\hline Paralinhomeus & $1 \mathrm{~B}$ & & $1.7 \pm 1.7$ & & & & & & \\
\hline Paranticoma & $2 \mathrm{~A}$ & & & & & & & & $0.7 \pm 0.4$ \\
\hline
\end{tabular}


Table 3 (continued)

\begin{tabular}{|c|c|c|c|c|c|c|c|c|c|}
\hline Genera & FT & \multicolumn{3}{|c|}{ Canyon system } & S24 & $\mathrm{S} 22$ & S39 & $\begin{array}{c}\text { Open slope } \\
\text { S27 }\end{array}$ & S25 \\
\hline Pareudesmocolex & $1 \mathrm{~A}$ & & & & & & $0.2 \pm 0.2$ & & \\
\hline Parasphaerolaimus & $2 \mathrm{~B}$ & & $0.2 \pm 0.2$ & & & & & & \\
\hline Pierrickia & $1 \mathrm{~B}$ & & & & & & & $3.5 \pm 1.7$ & \\
\hline Polysignia & $2 \mathrm{~A}$ & & & & & & & $0.4 \pm 0.4$ & \\
\hline Pomponema & $2 \mathrm{~B}$ & $0.5 \pm 0.3$ & $0.2 \pm 0.2$ & & & & $2.1 \pm 1.1$ & $0.4 \pm 0.4$ & \\
\hline Prooncholaimus & $2 \mathrm{~B}$ & $0.5 \pm 0.3$ & & & & & & & \\
\hline Pselionema & $1 \mathrm{~A}$ & & & & & $0.2 \pm 0.2$ & $2.6 \pm 1.4$ & $0.7 \pm 0.7$ & \\
\hline Pterygonema & $1 \mathrm{~A}$ & & & & & & $0.2 \pm 0.2$ & & \\
\hline Quadricoma & $1 \mathrm{~A}$ & & & & & & $0.7 \pm 0.5$ & & \\
\hline Sabatieria & 1B & $2.6 \pm 0.7$ & $53.1 \pm 21.3$ & $0.5 \pm 0.3$ & $7.6 \pm 2.8$ & $1.1 \pm 0.5$ & $11.1 \pm 1.9$ & $14.1 \pm 4.0$ & $0.4 \pm 0.4$ \\
\hline Setosabatieria & 1B & & $0.2 \pm 0.2$ & & & & $4.7 \pm 1.5$ & $3.9 \pm 1.9$ & \\
\hline Sphaerolaimus & $2 \mathrm{~B}$ & $0.7 \pm 0.3$ & $1.4 \pm 1.4$ & $0.2 \pm 0.2$ & $1.4 \pm 0.8$ & $0.2 \pm 0.2$ & $1.9 \pm 1.0$ & $3.9 \pm 2.0$ & $0.4 \pm 0.4$ \\
\hline Subsphaeroplimus & $2 \mathrm{~B}$ & & & & & & $0.7 \pm 0.7$ & $0.4 \pm 0.4$ & \\
\hline Steineria & 1B & & & & & & & $0.4 \pm 0.4$ & \\
\hline Synodontium & 1B & & & & & & $0.2 \pm 0.2$ & & \\
\hline Synonchiella & $2 \mathrm{~B}$ & & & & & & $0.2 \pm 0.2$ & $0.4 \pm 0.4$ & \\
\hline Syringolaimus & $2 \mathrm{~B}$ & & & & & $1.4 \pm 0.6$ & & $0.7 \pm 0.4$ & $0.4 \pm 0.4$ \\
\hline Terschellingia & $1 \mathrm{~B}$ & $1.2 \pm 0.7$ & $1.4 \pm 1.4$ & & & $1.1 \pm 0.6$ & $2.8 \pm 0.6$ & $0.4 \pm 0.4$ & $1.1 \pm 1.1$ \\
\hline Thalassoalaimus & $1 \mathrm{~A}$ & & & & & & $0.2 \pm 0.2$ & & \\
\hline Thalassomonhystera & 1B & & & & & $0.2 \pm 0.2$ & $0.2 \pm 0.2$ & & \\
\hline Thoracostomopsis & 2B & & & & & & & $0.4 \pm 0.4$ & \\
\hline Vasostoma & $2 \mathrm{~A}$ & & $0.2 \pm 0.2$ & & $0.6 \pm 0.3$ & $0.4 \pm 0.2$ & & & \\
\hline Viscosia & $2 \mathrm{~B}$ & $0.2 \pm 0.2$ & & & $0.6 \pm 0.3$ & $0.7 \pm 0.4$ & $2.8 \pm 0.7$ & $1.1 \pm 1.1$ & \\
\hline Wieseria & $1 \mathrm{~A}$ & & & & & & $0.7 \pm 0.7$ & & \\
\hline Total & & $24.8 \pm 11.8$ & $153.5 \pm 72.2$ & $5.9 \pm 3.1$ & $35.9 \pm 18.0$ & $8.3 \pm 5.6$ & $103.5 \pm 41.4$ & $72.9 \pm 32.5$ & $14.5 \pm 10.0$ \\
\hline No genera & & 18 & 23 & 6 & 30 & 21 & 51 & 41 & 20 \\
\hline
\end{tabular}
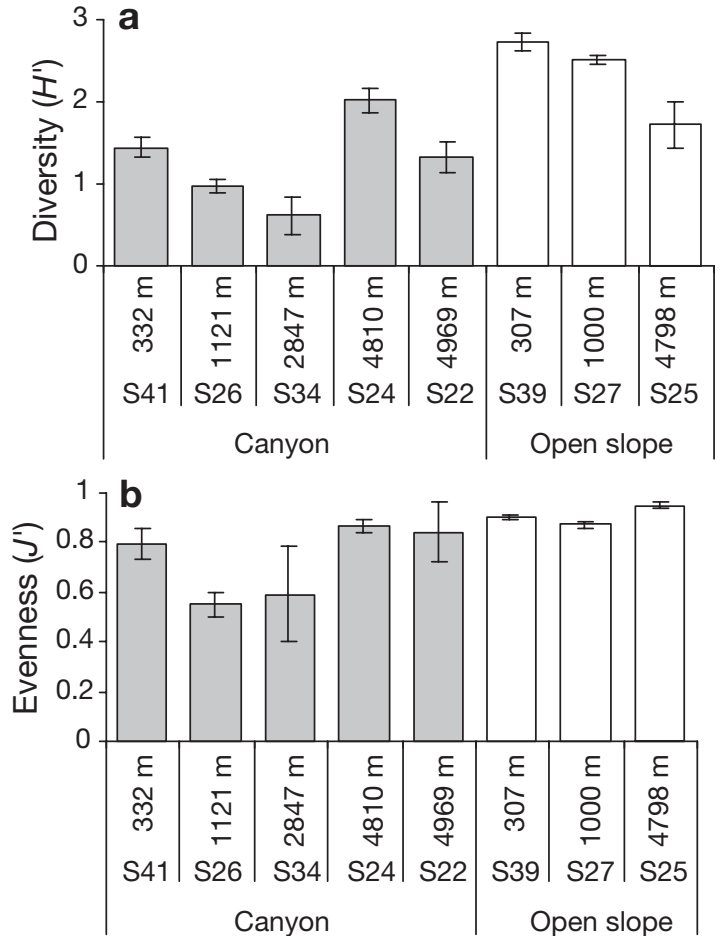

Fig. 5. Mean \pm SE (a) diversity (Shannon-Wiener $H^{\prime}$ ), and (b) evenness $\left(J^{\prime}\right)$ of nematode assemblage along bathymetric gradient and at Stns S41, S26, S34, S24, S22, S39, S27 and S25 in Nazaré canyon and on adjacent open slope

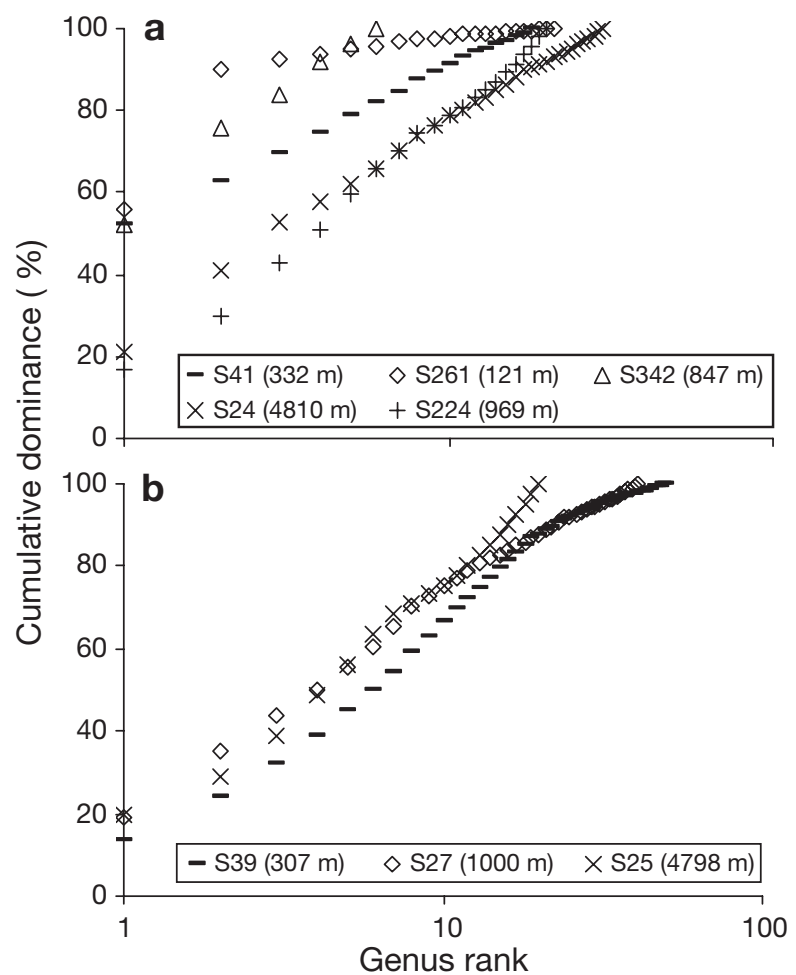

Fig. 6. Nematode abundance $K$-dominance curves along depth gradient in (a) Nazaré canyon and (b) adjacent openslope stations 

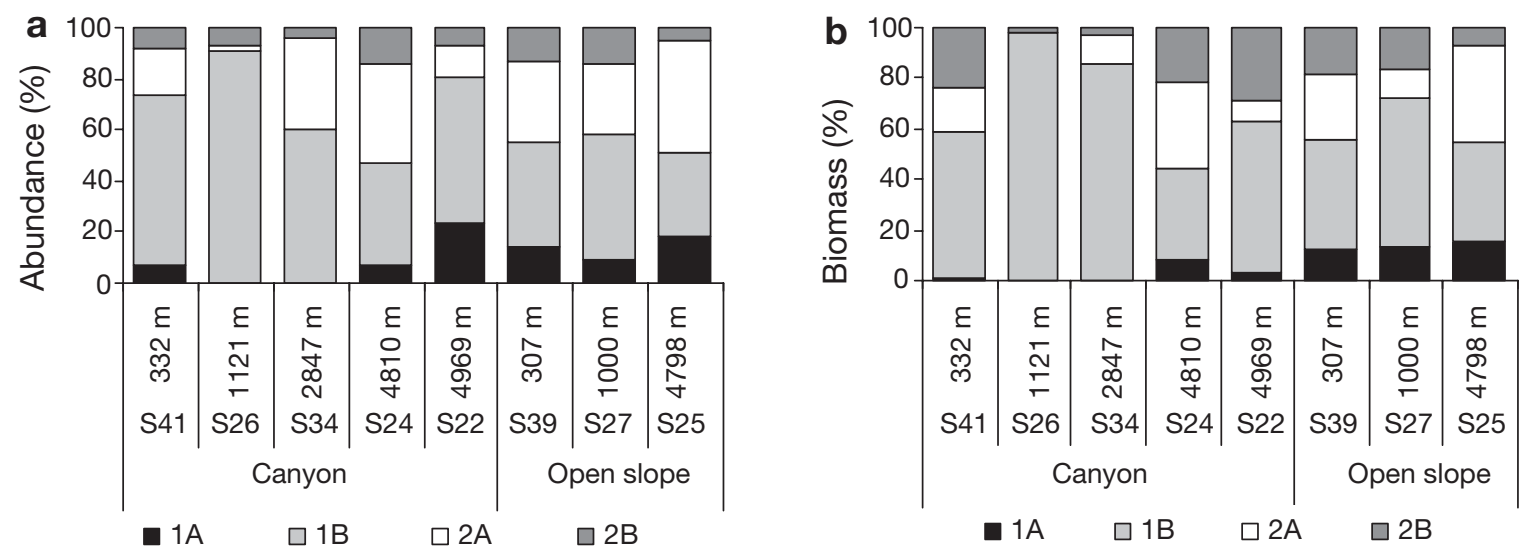

Fig. 7. (a) Relative abundance and (b) biomass of nematodes belonging to the 4 different feeding types described by Wieser (1953), along bathymetric gradient and at Stns S41, S26, S34, S24, S22, S39, S27 and S25 in Nazaré canyon and on adjacent open slope $(1 \mathrm{~A}=$ selective deposit-feeder, $1 \mathrm{~B}=$ non-selective deposit-feeder, $2 \mathrm{~A}=$ epigrowth feeder, $2 \mathrm{~B}=$ predator/omnivor $)$

nematodes (Feeding Type 1B) dominated in terms of abundance (Fig. 7a) and biomass (Fig. 7b). The assemblages of the upper and middle part of the canyon differed from that in the deeper part: Non-selective deposit feeders (Type 1B) were dominant in the upper and middle canyon areas, whereas selective deposit feeders (Type 1A) were unimportant; however, the latter feeding type was more important in the deeper part of the canyon, where it was present in proportions similar to those on the open slope.

\section{Relationships between benthic meiofauna and geochemical parameters}

The correlation analysis revealed different levels of interactions for the canyon system and adjacent open slope (Table 4). In the canyon there were 21 correlations, with an average Kendall's tau correlation coefficient of 0.5 . The abundance of total metazoans, copepods, polychaetes, bivalves, nematodes and also nematode biomass were positively correlated $(p \leq 0.01)$ with the lability of the phytodetritus (chl a:phaeo). Diversity and evenness were negatively correlated with Corg $(p \leq 0.01)$ and phytodetritus $(\mathrm{CPE})$ content ( $p \leq 0.05$ and 0.01 respectively). The nematode trophic group 1B was positively correlated with chl a:phaeo $(p \leq 0.01)$ and CPE $(p \leq 0.01)$. On the open slope, there were 13 correlations with an average Kendall's tau correlation coefficient of 0.6. The abundance of total metazoans, copepods, polychaetes, nematodes and the nematodes biomass was positively correlated with CPE ( $p \leq 0.01$, nematode biomass $p \leq 0.05$ ). Diversity was also positively correlated with CPE $(p \leq 0.05)$, as were the nematode trophic groups $1 \mathrm{~B}, 2 \mathrm{~A}(\mathrm{p} \leq 0.01)$ and $2 \mathrm{~B}$ $(\mathrm{p} \leq 0.05)$.

\section{DISCUSSION}

\section{Meiofauna and organic matter levels}

The meiofauna abundance recorded in the Nazare canyon and adjacent open slope ranged between 9.9 and 236.5 ind. $10 \mathrm{~cm}^{-2}$. These values are low compared to those in temperate regions of the east Atlantic and off the Iberian Peninsula (see Soltwedel 2000), but within the range observed during springtime in the Western Iberian Margin. Most present-day studies on meiofauna use a mesh size $\leq 32 \mu \mathrm{m}$. We used a $48 \mu \mathrm{m}$ mesh size, which could have underestimated actual meiofauna densities. Using a comparable mesh size $(50 \mu \mathrm{m})$, Rachor (1975) found meiofauna abundances at $38^{\circ} \mathrm{N}\left(\sim 1^{\circ} \mathrm{S}\right.$ from the Nazare study area) ranging between 18 and 294 ind. $10 \mathrm{~cm}^{-2}$ during springtime at depths of 1469 to $5112 \mathrm{~m}$. In wintertime, also at $38^{\circ} \mathrm{N}$, and using a $40 \mu \mathrm{m}$ mesh size, Thiel (1975) recorded meiofauna abundances ranging between 123 and 1387 ind. $10 \mathrm{~cm}^{-2}$ at depths of 250 to $5250 \mathrm{~m}$, suggesting strong seasonality. On the NW Iberian margin $\left(42\right.$ to $\left.43^{\circ} \mathrm{N}\right)$ during summertime, Flach et al. (2002) observed meiofauna abundances ranging between 250 and 1800 ind. $10 \mathrm{~cm}^{-2}$, at depths of 200 to $5000 \mathrm{~m}$, but they used a smaller $32 \mu \mathrm{m}$ mesh size. In terms of biomass, the values recorded for the Nazaré canyon and adjacent open slope are about 3 to 4 times lower than those reported for the NW Iberian margin during summer (Flach et al. 2002).

The average Corg content of the top $5 \mathrm{~cm}$ of sediment in the Nazaré canyon ranged between 1.52 and $1.86 \%$, while on the adjacent open slope Corg contents ranged between 0.3 and $1.02 \%$. These values are similar to those found in the past for the Nazaré canyon and slope in the NW Iberian margin (Epping et al. 


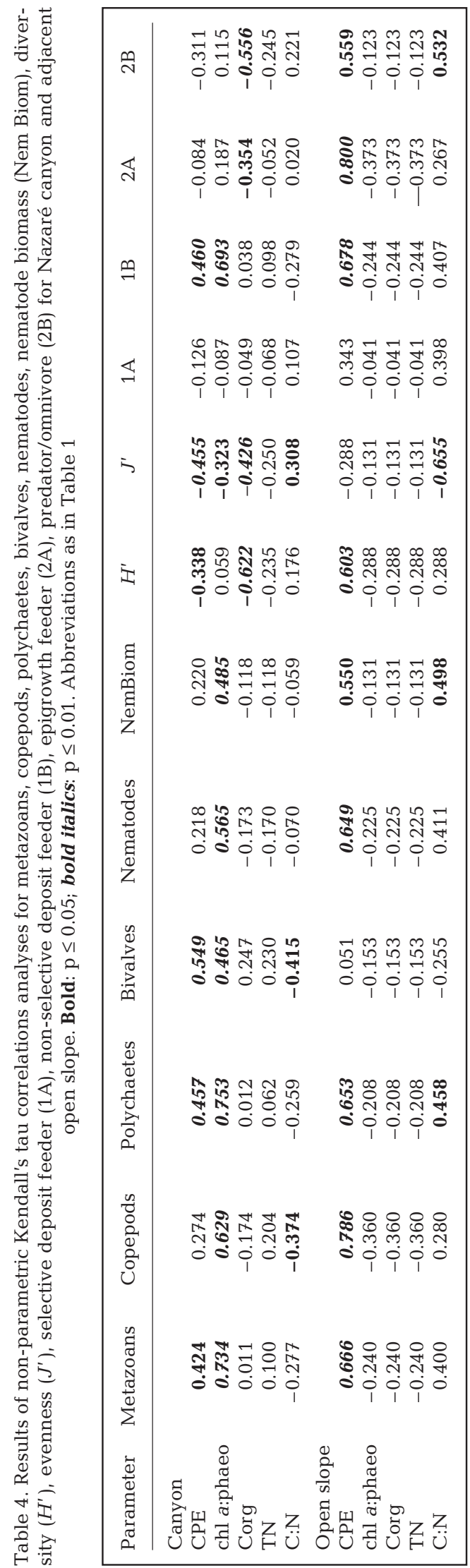

2002). At other continental margins, similar Corg contents have also been observed (Duineveld et al 2001, Grémare et al. 2002).

The CPE ranged between 5.7 and $92.4 \mu \mathrm{g} 5 \mathrm{~cm}^{-3}$ in the Nazaré canyon sediments, and between 1.7 and $22.3 \mu \mathrm{g} 5 \mathrm{~cm}^{-3}$ on the open slope. The open-slope values fall within the range given for other continental margins at similar depths (Soltwedel 1997, Soltwedel et al. 2000). In contrast, the values we found in the Nazaré canyon sediments are several others of magnitudes higher than those found in other continental margins.

The lability of the phytodetritus in the canyon and adjacent slope sediments is refractory compared to that of other continental margins at similar depths. Soltwedel et al. (2000) found chl a: phaeo ratios of 0.4 to 0.7 at $\sim 500 \mathrm{~m}$, of 0.07 to 0.21 at $\sim 1000 \mathrm{~m}$, of 0.03 to 0.12 at $\sim 3000 \mathrm{~m}$ and of 0.05 at $\sim 4000 \mathrm{~m}$ depths on the Yermak Plateau. In the canyon and adjacent slope sediments chl a:phaeo ratios ranged between 0.02 and 0.18 .

\section{Distribution of meiofauna abundance and biomass}

For continental margins, the abundance and biomass of benthic communities have been reported to decrease with increasing water depth (Tietjen 1992, Soltwedel 2000, Flach et al. 2002). This decrease has been related to decreased food availability (Gage \& Tyler 1991). In the canyon and adjacent open-slope sediments, phytodetritus decreased with increasing water depth, and Corg content tended to be lower at greater depths (Table 1). However, a parallel decrease in meiofauna abundance and biomass only occurred on the open slope (Fig. 4). This is supported by the stronger positive correlation between the metazoan taxa and CPE contents on the open slope than in the canyon (Table 4).

For submarine canyons, higher abundances of fauna and higher biomasses have been reported and related to the higher organic content of these environments (Gage et al. 1995, Vetter \& Dayton 1998, Duineveld et al. 2001). Moreover, the quality of organic matter also plays an important role in controlling benthic communities. In areas with high quantities of labile organic matter, faunal density and biomass have been found to be higher than in areas where similar quantities of refractory organic matter were observed (Dauwe \& Middelburg 1998).

Higher organic contents (Corg, TN and CPE) were found throughout the canyon than on the adjacent slope, especially in the upper/middle parts (Table 1). Despite the fact that the bulk of the organic matter in the canyon was very refractory ( $\mathrm{C}: \mathrm{N} \approx 9$ to 12 ), the amount and quality of organic matter available for 
direct consumption was higher in the upper part of the canyon (higher CPE contents and chl a:phaeo ratios) (Table 1). This suggests that the upper and middle canyon areas would constitute better feeding grounds for the benthos, and higher densities and biomass would be expected there. However, higher meiofaunal abundance and nematode biomass were not always observed in the canyon. Although meiofaunal densities in the deeper parts of the canyon seemed to parallel environmental organic levels, in the upper and middle areas this was not the case. Stns S41, S26 and S34 were always depleted in foraminifers compared to the open slope (Fig. 3). Metazoans in general, and polychaetes and nematodes specifically (Fig. 4) were very abundant at St S26 (1121 m), but were depleted at St S41 and S34. This was also true for nematode biomass. In general, organisms on the adjacent open slope seemed to survive better with lower or similar background levels of Corg and CPE than those in the canyon.

The absence of a clear relationship between faunal abundance and biomass with organic content and metabolisable organic matter in the canyon suggests that some other environmental parameter(s) is/are responsible for faunal distributions. De Stigter et al. (2007) measured high near-bed tidal currents, average horizontal particle flux and deposition flux in the upper and middle parts of Nazaré canyon. The high currents may cause frequent resuspension and transport of surface sediments, leading to unstable sediment substrate, and high sedimentation rates may lead to fauna being buried by sediment. Such an environment is difficult to colonise because the meiofauna is either swept away by high currents or buried by unstable sediments and episodic depositional events, as confirmed by the lack of fragile arborescent foraminifers in the upper and middle canyon. Gage et al. (1995) also reported the absence of fragile surface-feeding macrofauna in the Setúbal canyon, where indications of vigorous bottom currents were found. In the Nazaré canyon, low numbers of calcareous and agglutinated foraminifers were found in the upper and middle parts. Previously, low abundances of foraminifers were recorded in the Wilmington canyon off the coast of New Jersey, and their absence was related to periodic mass wasting and high current activity in the study area (Jorissen et al. 1994). Further, the nematodes Sabatieria sp. and Metalinhomoeus sp., which have been shown to persist and thrive in very disturbed environments resulting from dredging and trawling activities (Schratzberger \& Jennings 2002) were very dominant in the upper and middle parts of the Nazaré canyon. These observations seem to indicate that meiofauna abundance and biomass in the upper and middle canyon is strongly controlled by physical factors.

\section{Nematode community structure}

In the upper and middle parts of the Nazaré canyon, higher phytopigments and Corg concentrations were recorded, and the phytodetritus was less refractory. Here, low nematode diversity and evenness, and high $K$-dominance curves were found, and non-selective deposit-feeding nematodes were especially important. In agreement, the correlation analyses showed negative correlations of diversity and evenness with Corg and $\mathrm{CPE}$, and a positive correlation of non-selective deposit-feeders with CPE and chl a:phaeo (Table 4). In the deeper canyon area and adjacent open slope, lower contents of phytopigments and Corg were recorded, and the phytodetritus was more refractory. Higher diversity and evenness, and lower K-dominance curves were found here. The trophic structure of the nematode assemblages was more diverse. The correlation analysis supported this, showing a positive correlation of diversity with $\mathrm{CPE}$, and a higher number of trophic groups correlated to CPE (Table 4). Thus, diversity patterns of the nematode community and trophic structure both indicate that the differences in metabolisable organic matter between upper canyon regions and adjacent open slope, and deeper canyon regions play an important role in controlling the composition of the meiobenthos inhabiting these regions.

Two nematode genera, Sabatieria sp. and Metalinhomoeus sp., accounted for $\sim 70 \%$ of the abundance in the upper canyon (Fig. 6a). Both these genera are nonselective deposit-feeders. Sabatieria sp. is well adapted to living in fine-sediment environments, with high Corg loads, low oxygen concentrations, and high sulphide concentrations (Jensen et al. 1992, Soetaert \& Heip 1995). Suboxic sediments also characterise the upper part of the Nazaré canyon (Epping et al. 2002). Metalinhomoeus sp. has also been found to be very abundant in silty and very fine sand environments with high Corg content (Buchholz \& Lampadariou 2002). Further, these genera are also found in highly physically-disturbed sedimentary conditions resulting from dredging and trawling. Thus, in the more disturbed and organically enriched conditions of the upper canyon, Sabatieria sp. and Metalinhomoeus sp. may constitute opportunistic colonisers. Flach (2003) also found that the macrobenthic community in the Nazaré canyon was dominated by 2 small opportunistic polychaetes.

\section{CONCLUSIONS}

The Nazaré canyon contains higher amounts of organic matter than the adjacent open slope. In its upper and middle parts, the phytodetritus is fresher, 
and thus of higher nutritional value for the meiobenthos. However, contrary to expectations, the meiobenthos in this part of the canyon seem unable to fully exploit the high amounts of food resources the canyon provides. In comparison, the meiobenthos on the open slope is more abundant, although with less abundant food resources. The low abundance of fauna in the canyon may be due to the local high-velocity bottom currents and unstable sedimentary conditions hindering the settlement of meiobenthic communities. The upper canyon was dominated by 2 very opportunistic nematode genera (Sabatieria sp. and Metalinhomoeus sp.) that are able to withstand great sedimentary disturbance, high organic loads and suboxic conditions. The nematode community structure was related to organic concentrations. In the organically enriched upper canyon, lower diversities of the nematode assemblages and of the trophic structure were observed. Finally, the stations sampled in the canyon were situated in the thalweg, where physical disturbance by sediment transport and deposition is likely to be highest. A comparison with potentially less disturbed sites on terraces adjacent to the thalweg has yet to be made.

Acknowledgements. This research was supported by EUROSTRATAFORM project, EC contract EVK3-CT-200200079 funded by the European Commission, DG-XII, and the HERMES project, EC contract OCE-CT-2005-511234 funded by the European Commission's Sixth Framework Programme under the priority Sustainable Development, Global Change and Ecosystems. Shiptime on RV 'Pelagia' was provided by Royal NIOZ, Texel, The Netherlands. The authors thank all the crew of the research vessel 'Pelagia' for their work in getting the samples on deck, Dr. T. J. Kouwenhoven for helping out with sample processing on board and comments on the manuscript, and Dr. T. Soltwedel and Dr. C. Hasseman for providing the semiautomatic images system (analySIS ${ }^{\circledR} 2.1$ ) from the Alfred Wegener Institut. We also thank Dr. A. Lerchl from Jacobs University Bremen for providing microscopes, and the students A. Palacz (for his help with phytopigment analyses) and B. Alexander (for proof-reading the English of the manuscript).

\section{LITERATURE CITED}

Andrassy I (1956) Die Rauminhalts und Gewichtsbestimmung der Fadenwuermer (Nematoden). Acta Zool Acad Sci Hung, 1-3:1-15

Buchholz TG, Lampadariou N (2002) Changes in composition and diversity of the Malia Bay nematode community (Crete, Greece) in relationship to sediment parameters. In: Bright M, Dworschak PC, Stachowitsch M (eds) Vienna School of Marine Biology: a tribute to Jörg Ott. Facultas Universitätsverlag, Wien, p 33-52

Coelho H, Garcia AC, Neves R (2003) Aspects of circulation over submarine canyons: a numerical study. 4th Symposium on the Iberian Atlantic Margin. Thalassas (Rev Cienc Mar Santiago de Compostela) 19:141-143

Curdia J, Carvalho S, Ravara A, Gage JD, Rodrigues AM, Quintino V (2004) Deep macrobenthic communities from
Nazaré submarine canyon (NW Portugal). Sci Mar 68: 171-180

Dauwe B, Middelburg JJ (1998) Amino acids and hexosamines as indicators of organic matter degradation state in North Sea sediments. Limnol Oceanogr 43:782-798

De Stigter HC, Boer W, De Jesus Mendes PA, Jesus CC, Thomsen L, Van den Bergh GD, Van Weering TCE (2007) Recent sediment transport and deposition in the Nazaré Canyon, Portuguese continental margin. Mar Geol (Spec Iss) (in press). doi:10.1016/j.margeo.2007.04.011

Duineveld G, Lavaleye M, Berghuis E, de Wilde P (2001) Activity and composition of the benthic fauna in the Whittard Canyon and the adjacent continental slope (NE Atlantic). Oceanol Acta 24:69-83

Epping E, van der Zee C, Soetaert K, Helder W (2002) On the oxidation and burial of organic carbon in sediments of the Iberian margin and Nazaré Canyon (NE Atlantic). Prog Oceanogr 52:399-431

Flach E (2003) Factors controlling soft bottom macrofauna along and across European continental margins. In: Wefer G, Billet D, Hebbeln D, Jørgensen B B, Schlüter M, van Weering $\mathrm{T}$ (eds) Ocean margin systems. Springer-Verlag, Berlin, p 351-363

Flach E, Muthumbi A, Heip CHR (2002) Meiofauna and macrofauna community structure in relation to sediment composition at the Iberian margin compared to the Goban Spur (NE Atlantic). Prog Oceanogr 52:433-457

Gage JD, Tyler PA (1991) Deep-sea biology: a natural history of organisms at the deep-sea floor. Cambridge University Press, Cambridge

Gage JD, Lamont PA, Tyler PA (1995) Deep-sea macrobenthic communities at contrasting sites off Portugal, Preliminary Results. 1. Introduction and diversity comparisons. Int Rev Gesamten Hydrobiol 80:235-250

Garcia C, Coelho H, Neves R (2003) Some hydrological and nephelometric aspects over Nazaré and Setúbal (Portugal) submarine canyons. 4th Symposium on the Iberian Atlantic Margin, Thalassas (Rev Cienc Mar Santiago de Compostela) 19:51-52

Grémare A, Medernach L, de Bovee F, Amouroux JM, Vétion G, Albert P (2002) Relationships between sedimentary organics and benthic meiofauna on the continental shelf and the upper slope of the Gulf of Lion (NW Mediterranean). Mar Ecol Prog Ser 234:85-94

Jensen P (1984) Measuring carbon content in nematodes. Helgol Meeresunters 38:83-86

Jensen P, Rumohr J, Graf G (1992) Sedimentological and biological differences across a deep-sea ridge exposed to advection and accumulation of fine-grained particles. Oceanol Acta 15:287-296

Jorissen FJ, Buzas MA, Culver SJ, Kuehl SA (1994) Vertical distribution of living benthic foraminifera in submarine canyons off New Jersey. J Foraminifer Res 24:28-36

Krebs CJ (1989) Ecological methodology. Harper \& Row, New York.

Lambshead PJD, Platt HM, Shaw KM (1983) The detection of differences among assemblages of marine benthic species based on an assessment of dominance and diversity. J Nat Hist 17:859-874

Leguerrier D, Niquil N, Boileau N, Rzeznik J, Sauriau PG, Le Moine O, Bacher C (2003) Numerical analysis of the food web of an intertidal mudflat ecosystem on the Atlantic coast of France. Mar Ecol Prog Ser 246:17-37

Lohse L, Kloosterhuis RT, de Stigter HC, Helder W, van Raaphorst W, van Weering TCE (2000) Carbonate removal by acidification causes loss of nitrogenous compounds in continental margin sediments. Mar Chem 69:193-201 
Maurer D, Robertson G, Gerlinger T (1994) Comparison of community structure of soft-bottom macrobenthos of the Newport submarine canyon, California and the adjoining shelf. Int Rev Ges Hydrobio 79:591-603

Ólafsson E, Elmgren R (1997) Seasonal dynamics of sublittoral meiobenthos in relation to phytoplankton sedimentation in the Baltic Sea. Estuar Coast Shelf Sci 45:149-164

Pielou EC (1969) An introduction to mathematical ecology. Wiley-Interscience, New York

Puig P, Ogston AS, Mullenbach BL, Nittrouer CA, Parson JD, Sternberg RW (2004) Storm-induced sediment gravity flows at the head of the Eel submarine canyon, northern California margin. J Geophys Res, 109, C03019, doi: 10.1029/2003JC001918

Rachor E (1975) Quantitative Untersuchungen über das Meiobenthos der nord-atlantischen Tiefsee. Meteor Forschergeb D 21:1-10

Schratzberger M, Jennings S (2002) Impacts of chronic trawling disturbance on meiofaunal communities. Mar Biol 141: 991-1000

Shuman FR, Lorenzen CF (1975). Quantitative degradation of chlorophyll by a marine herbivore. Limnol Oceanogr 20: 580-586

Soetaert K, Heip CHR (1995) Nematode assemblages of deepsea and shelf break sites in the North Atlantic and Mediterranean Sea. Mar Ecol Prog Ser 125:171-138

Soltwedel T (1997) Meiobenthos distribution pattern in the tropical East Atlantic: indication for fractionated sedimentation of organic matter to the sea floor? Mar Biol 129:747-756

Soltwedel T (2000) Metazoan meiobenthos along continental margins: a review. Prog Oceanogr 46:59-84

Editorial responsibility: Howard Browman (Associate Editorin-Chief), Storebø, Norway
Soltwedel T, Mokievsky V, Schewe, I (2000) Benthic activity and biomass on the Yermak Plateau and in adjacent deepsea regions northwest of Svalbard. Deep-Sea Res I 47: 1761-1785

Thiel H (1975) The size structure of the deep-sea benthos. Int Rev Gesamten Hydrobiol 60:575-606

Thiel H (1978) Benthos in upwelling regions. In: Boje R, Tomczak M (eds) Upwelling ecosystems. Springer-Verlag, Berlin, p 124-138

Tietjen JH (1992) Abundance and biomass of metazoan meiobenthos in the deep sea. In: Rowe GT, Pariente V (eds) Deep-sea food chains and the global carbon cycle. Kluwer Academic, London, p 45-62

Vanney JR, Mougenot D (1981) La plate-forme continentale du Portugal et les provinces adjacentes: analyse géomorphologique. Mem Serv Geol Portug 28:1-86

Van Weering TCE, De Stigter HC, Boer W, De Haas H (2002) Recent sediment transport and accumulation on the NW Iberian margin. Prog Oceanogr 52:349-371

Vetter EW, Dayton PK (1998) Macrofaunal communities within and adjacent to a detritus-rich submarine canyon system. Deep-Sea Res II 45:25-54

Vitorino J, Oliveira A, Jouanneau JM, Drago T (2002) Winter dynamics on the northern Portuguese shelf. Part 1. Physical processes. Prog Oceanogr 52:129-153

Wieser W (1953) Die Beziehung zwischen Mundhohlengestalt Ernahrungsweise und Vorkommen bei freilebenden marinen Nematoden. Ark Zool 26:439-484

Yentsch CS, Menzel DW (1963) A method for the determination of phytoplankton chlorophyll and phaeophytin by fluorescence. Deep-Sea Res 10:221-231

Submitted: June 15, 2006; Accepted: October 6, 2006

Proofs received from author(s): May 25, 2007 